\title{
Thistle (Cynara cardunculus L) flower as a coagulant agent for cheesemaking. Short characterization
}

\author{
AP Louro Martins ${ }^{1}$, MM Pestana de Vasconcelos ${ }^{1}$, RB de Sousa ${ }^{2}$ \\ ${ }^{1}$ Laboratório Ferreira Lapa, Núcleo de Tecnologia do Leite e Derivados, Estação Nacional \\ de Tecnologia dos Produtos Agrários, Instituto Nacional de Investigação Agrária, Tapada da Ajuda; \\ 2 Departamento de Química Agrícola e Ambiental, Instituto Superior de Agronomia, \\ Tapada da Ajuda, 1300 Lisboa, Portugal
}

(Received 1 March 1995; accepted 29 April 1996)

\begin{abstract}
Summary - The use of Cynara cardunculus L as a coagulant for cheesemaking has been considered one of the most important factors for the quality of the Portuguese traditional ewe's milk cheeses, some of them benefiting of an 'Appellation d'Origine'. However, the irregularity of the traditional utilization of this coagulant agent is claimed to contribute to the poor quality and homogeneity of the cheese. After some work on thistle flower production, the study of the best conditions for its use in cheesemaking as well as the influence on cheese quality started with the flower characterization. Thistle flower from different origins and of different kinds of plants was analyzed for moisture, ash and total nitrogen content, water activity and milk clotting activity (MCA). A short characterization of the flower showed great variability mainly related with drying conditions. MCA was similar to that of liquid commercial coagulants. Drying of the flower seemed to affect MCA.
\end{abstract}

cheese / clotting enzyme / thistle flower / Cynara cardunculus

Résumé - La fleur du chardon (Cynara cardunculus $L$ ) comme coagulant pour la fabrication de fromage. Caractérisation succinte. L'utilisation du chardon comme coagulant a été considérée comme l'un des facteurs déterminants de la qualité des fromages typiques portugais au lait de brebis, dont certains sont protégés par une appellation d'origine contrôlée. Cependant, l'utilisation du chardon pose des problèmes causés par l'empirisme et le manque de contrôle de son activité. $\dot{A}$ la suite d'études antérieures sur la production de fleur de Cynara cardunculus, on cherche actuellement à étudier des conditions de production plus avantageuses et l'influence de l'extrait coagulant sur la technologie de fabrication et la qualité du fromage. Ce travail présente les résultats obtenus pour la caractérisation de la fleur de chardon. La fleur de Cynara cardunculus provenant de plusieurs sources a été analysée par rapport aux teneurs en matière sèche, cendre, azote total, $a_{w}$ et activité enzymatique. Cette caractérisation succinte montre une grande variabilité de résultats, due surtout aux différents degrés de séchage des échantillons, dont les teneurs en eau variaient de $6 \%$ à $47 \%$. L'activité coagulante (1:9000-1:12000) était très semblable à celle des coagulants liquides du commerce. La méthode traditionnelle de séchage de la fleur semble avoir une influence sur l'activité enzymatique qui, exprimée par rapport à la teneur en eau et à la teneur en azote total, présente, pour la fleur sèche. des diminutions significatives ( $32 \%$ et $26 \%$ ). 
fromage / enzyme coagulante / fleur de chardon / Cynara cardunculus

\section{INTRODUCTION}

The traditional use of thistle flower (Cynara cardunculus $\mathrm{L}$ ) as the coagulant agent of Portuguese ewe's milk traditional cheese is well known (Rasteiro, 1905; Vieira de Sá, 1974; Barbosa, 1983). It is even considered one of the most important factors for the high quality of those cheeses (Matos and Vieira de Sá, 1948). Some of them benefit of an 'Appellation d'Origine' and the respective legislation imposes the use of this vegetal coagulant on the cheesemaking technology (Holstein, 1988; Vasconcelos, 1991).

Studies on thistle flower as a coagulant agent for cheesemaking come mainly from Portugal, Spain and South America. The concern enzyme characterization, technological factors and importance for cheese quality (Christen and Virasoro, 1935; Vieira de Sá and Barbosa, 1972; Tsouli, 1974; Marcos et al, 1978; Campos et al, 1990; Nuñez et al, 1991). Recently, vegetable coagulants of traditional cheesemaking technologies were investigated because its empirical use is claimed to be one of the most important factors for the highly variable cheese quality, reducing its acceptability, especially in urban areas (Otani et al, 1984; Aworh and Muller, 1987; O'Connor, 1990; Heimgartner et al, 1990; Macedo et al, 1993).

Thus, the possibility of the use of a controlled coagulant can contribute to the improvement and the preservation of the traditional cheesemaking activity, which for many years already is responsible for some high-quality and very typical products like Serra da Estrela, Serpa and Azeitão cheeses.

Following previous work on traditional Portuguese cheeses (Vasconcelos et al, 1989; Vasconcelos, 1991) and thistle flower production (Morbey, 1990), we in- tend to study the improvement of thistle flower production, conservation and utilization conditions, to achieve a better rationalization of cheesemaking and an improvement of cheese quality. In this paper we examine the first results obtained with a short characterization of thistle flower.

\section{MATERIALS AND METHODS}

Thistle flowers from different origins and different types of plants, harvested during flower season, were analyzed for moisture (drying at $101^{\circ} \mathrm{C} \pm$ $1^{\circ} \mathrm{C}$ ), total nitrogen (Kjeldhal), ash (incineration at $550-600^{\circ} \mathrm{C}$ ) and water activity ( $\mathrm{a}_{\mathrm{w}}$; Rotronic Hygroskop DT, Rotronic AG). The different samples were taken from batches of non-dried and traditionally dried ( 30 days) flowers, and analyzed the day after the gathering of the flower. Also included were three samples of flower dried traditionally for a period of 1 day (referred to as medially dried flower).

For the determination of MCA we used thistle flower extracts prepared by maceration at $30^{\circ} \mathrm{C}$ in a mortar, with $5 \% \mathrm{NaCl}$ ( $1 \mathrm{~g}$ dry matter $/ 50 \mathrm{~mL}$ ). After $24 \mathrm{~h}$, the mixture was filtered in a Whatman no 40 filter paper. The filtrate was analyzed for $\mathrm{pH}$, total nitrogen (Kjeldhal) and MCA following the British Standard BS 3624 (BSI, 1963), which is based on work of Berridge (1952). Skim milk powder (Oxoid, L31) reconstituted to $12 \%$ with a $0.01 \mathrm{~mol} / \mathrm{L} \mathrm{CaCl}_{2}$ solution was used as the reference milk for MCA determination. Calf rennet standard (CHR. Hansen's Lab, Denmark) with MCA of $1: 13250$ (f-Soxhlet method), $90 \mathrm{RU} / \mathrm{mL}$ (Rennet Units, Berridge method) or $50 \mathrm{CHU} / \mathrm{mL}$ (CHR Hansen Units) (Alais, 1985; Sponcet et al, 1985; Prins, 1988) was used as the reference rennet.

The MCA of the extract, expressed as percentage of MCA of reference rennet, was calculated from the clotting time by the expression:

$$
\frac{\mathrm{C} 1}{\mathrm{C} 2} \times \frac{\mathrm{t} 1}{\mathrm{t} 2} \times 100
$$

where $\mathrm{C} 1$ : concentration $(\mathrm{mL} / \mathrm{mL})$ of the reference rennet dilution; $\mathrm{C} 2$ : concentration $(\mathrm{mL} / \mathrm{mL})$ of the extract dilution; $t 1$ : clotting time (s) for the 
reference rennet; t2: clotting time (s) for the extract, considering a reference rennet MCA of 100 . The results expressed as $f$ or RU were obtained considering the MCA of the reference rennet expressed in those units.

All the determinations were made in triplicate. For result analysis we used descriptive statistics and analysis of variance (ANOVA), using the Scheffe test (Danzart, 1986) for comparisons of sample groups.

\section{RESULTS AND DISCUSSION}

From the global results of the short characterization of thistle flower we obtained a great variability of the different parameters, with a wide variation partially due to the drying degree of the flower. The moisture content varied from $6.15 \%$ to $47.32 \%$, affecting the results of almost all considered parameters, and MCA varied from 47.64 to $78.71 \mathrm{RU} / \mathrm{g}$ flower. Barbosa (1983) noted that the chemical composition of thistle flower varies with the batch and with the year, but in this work the variations found can be explained by the moisture range $(6 \%$ to $47 \%)$, which is due to the flower's different drying degrees. Under these conditions, the global results do not have great significance.

The results of the aggregation of samples according to the drying degree are shown in table I. The results obtained for the dried and medially dried flower were very similar, with moisture, total nitrogen and ash contents close to the results of Barbosa (1983) and Morbey (1990), and with low $a_{w}$ which indicates a good keeping ability. In fact, traditionally dried flower is usually used during the whole traditional cheesemaking season (from October to May), although clotting activity decreases with flower keeping (Antunes and Santos, 1943).

Table I. Short characterization of thistle flower. Caractéristiques de la fleur du chardon.

\begin{tabular}{lcccccc}
\hline & \multicolumn{2}{c}{$\begin{array}{c}\text { Dried flower } \\
(n=48)\end{array}$} & \multicolumn{2}{c}{$\begin{array}{c}\text { Non-dried flower } \\
(n=21)\end{array}$} & \multicolumn{2}{c}{$\begin{array}{c}\text { Medially dried flower } \\
(n=3)\end{array}$} \\
& Average & SD & Average & $S D$ & Average & $S D$ \\
\hline Chemical composition & & & & & & \\
Per 100 g flower & & & & & & \\
Dry matter (g) & $93.29^{\mathrm{a} *}$ & 0.42 & $61.37^{\mathrm{b}}$ & 5.89 & $89.93 \mathrm{a}$ & 0.06 \\
Total N (g) & $1.958^{\mathrm{a}}$ & 0.133 & $1.409^{\mathrm{b}}$ & 0.196 & $2.148^{\mathrm{a}}$ & 0.004 \\
Ash (g) & $4.36^{\mathrm{a}}$ & 0.41 & $3.44^{\mathrm{b}}$ & 0.28 & $4.32^{\mathrm{b}}$ & 0.03 \\
& & & & & & \\
Per 100 g dry matter & $2.009^{\mathrm{b}}$ & 0.141 & $2.294^{\mathrm{a}}$ & 0.204 & $2.392^{\mathrm{ab}}$ & 0.004 \\
Total N (g) & $4.65^{\mathrm{b}}$ & 0.40 & $5.60^{\mathrm{a}}$ & 0.28 & $4.81^{\mathrm{b}}$ & 0.03 \\
Ash (g) & & & & & & \\
Physical characteristics & & & & & & \\
aw & $0.592^{\mathrm{b}}$ & 0.047 & $0.866 \mathrm{a}$ & 0.058 & $0.674^{\mathrm{b}}$ & 0.004 \\
Clotting activity & & & & & & \\
RU/g flower & $64.30^{\mathrm{b}}$ & 7.01 & $62.02^{\mathrm{b}}$ & 6.65 & $77.85^{\mathrm{a}}$ & 0.75 \\
RU/g DM & $68.95^{\mathrm{b}}$ & 7.73 & $102.03^{\mathrm{a}}$ & 14.82 & $86.64^{\mathrm{a}}$ & 0.83 \\
RU/mgN flower & $3.30^{\mathrm{b}}$ & 0.45 & $4.47^{\mathrm{a}}$ & 0.73 & $3.64^{\mathrm{a}, \mathrm{b}}$ & 0.04 \\
\hline
\end{tabular}

${ }^{*}$ In the same row, different letters mean significant differences $(P<0.05)$.

* Sur une même ligne, les valeurs suivies de lettres différentes sont significativement différentes $(\mathrm{p}<0,05)$. 
The non-dried flower showed a moisture content of $30-47 \%$ and high $a_{w}$ values that indicate difficulties in keeping. In fact, after a few days at room temperature or at $4{ }^{\circ} \mathrm{C}$, the growth of molds and the sample degradation were evident. The MCA (RU/g flower) was higher for the medially dried flower, although this group had a significant lower number of samples than the others. Expressing MCA as a function of the dry matter (RU/g DM) and of the flower nitrogen content (RU/mg N flower), we can see that the higher MCA was obtained on the non-dried flower. Those results suggest that the traditional drying procedure can affect the MCA of thistle flower, with losses of $32 \%$ to $26 \%$ respectively, although the traditional drying procedure is not very drastic; the drying is achieved with low temperature $\left(25-30^{\circ} \mathrm{C}\right)$ with no direct incidence of sun light and during a variable time, frequently 30 to 60 days.

For all groups, MCA was close (1:10 151 to $1: 15022$ ) to that of the liquid commercial clotting enzymes or rennets $(1: 10000-$ 1:15000) and similar to the MCA described by Barbosa (1983) for the 'extracto impuro de cardo', a vacuum-dried thistle flower extract for cheesemaking.

The flower drying degree influenced the characteristics of thistle flower.

Considering the composition, these results were expected and showed that the 1-day dried flower group was not different from the dried flower group.

The differences for MCA (RU/g DM and $\mathrm{RU} / \mathrm{mg} \mathrm{N}$ flower) suggest that the drying procedure result in an important loss of the flower MCA. Similar results were obtained for other traditionally dried vegetable sources of proteolytic enzymes. Baeza et al (1990) described that the sun drying of papaya (Carica papaya L) latex often results in a partial inactivation of the proteolytic activity and that the use of newer methods, with controlled time and drying temperatures, will allow to obtain products with higher activity and less contamination and with more constant biochemical properties.

\section{CONCLUSION}

The short characterization of thistle flower shows a great variability in the composition, mainly due to the drying degree of the samples. This was dependent on previous drying of flower after harvesting. Results obtained for the dried flower were similar to those obtained by other authors.

Traditional drying procedures seem to affect the flower MCA. In fact, the MCA (RU/g $\mathrm{DM}$ and $\mathrm{RU} / \mathrm{mg} \mathrm{N}$ flower) was significantly lower for dried flower when compared with the non-dried flower. In both groups the results for MCA showed a wide variation (CV of $11 \%$ and $16 \%$ ) and this can mean that uncontrolled utilization of thistle flower may be an unfavorable factor for a stable cheesemaking technology as the extracts used are not standardized for milk clotting activity. Besides that, the high, non-specific proteolytic activity can also affect the technological steps and yield, as well as proteolysis rate during ripening (Vieira de Sá and Barbosa, 1972).

\section{REFERENCES}

Alais C (1985) Ciencia de la leche. Principios de tecnica lechera. Ed Reverté, SA, Barcelona

Antunes TM, Santos Al (1943) Elementos para o estudo do Queijo da Serra da Estrela. Bol Pec 11, 1-203

Aworh OC, Muller HG (1987) Cheesemaking properties of vegetable rennet from sodom apple (Calotropis procera). Food Chem 26, 71-79

Baeza G, Correa D, Salas C (1990) Proteolytic enzymes in Carica candamarcensis, J Sci Food Agric 51, 1-9

Barbosa M (1983) O cardo (Cynara cardunculus) como coagulante vegetal. $1^{\circ}$ Congr Nacional das Indústrias Agro-Alimentares, Lisboa, 22-25 de Março

Berridge NJ (1952) Observations on the determination of the activity of rennet. Analyst 77, 57-62

British Standards Institute - BSI (1963) Method for the determination of the milk coagulation power of rennet. British Standard 3624

Campos R, Guerra R, Aguilar M, Ventura O, Camacho $L$ (1990) Chemical characterization of proteases extracted from wild thistle (Cynara cardunculus). Food Chem 35, 89-97

Christen C, Virasoro E (1935) Présures végétales. Extraction et propriétés. Lait 15, 354-363 
Danzart M (1986) Univariate procedures. In: Statistical procedures in food research. (Piggott JR, ed) Elsevier, London, 19-59

Heimgartner U, Pietrzak M, Geertsen R, Brodelius P, Figueiredo ACS, Pais MSS (1990) Purification and partial characterization of milk clotting proteases from flowers of Cynara cardunculus. Phytochemistry 29, 1405-1410

Holstein FMS (1988) Queijos portugueses com Denominação de Origem. IQA, Julho de 1988

Macedo AC, Malcata FX, Oliveira JC (1993) The technology, chemistry and microbiology of Serra cheese: a review. J Dairy Sci 76, 1725-1739

Marcos A, Fernandéz-Salguero J, Esteban MA (1978) Anómala influencia de algunos factores en la hidrólisis relativa de las caseinas del queso por los cuajos vegetales (Cynara sp). Anal Bromatol 30, 314-320

Matos AAP, Vieira DE SÁ F (1948/49) Os coagulantes vegetal e animal na fabricação do queijo de ovelha. Bol Pec 16, 25-30

Morbey TM (1990) Projecto "Cardo". Relatório sucinto da actividade desenvolvida entre 1980 e 1990. INIA, ENTPA, Oeiras

Nuñez M, Pozo BF, Rodriguéz-Marín MA, Gaya A, Medina $M$ (1991) Effect of vegetable and animal rennet on chemical microbiological, rheological and sensory characteristics of La Serena cheese. J Dairy Res $58,511-519$

O'Connor CB (1990) Calotropis procera extract as a milk coagulant agent. $23^{\text {rd }}$ Int Dairy Congr A 20. October 7-12, Montreal
Otani H, Hosono A, Higashiyama S, Tokita F (1984) Some properties of the milk-clotting enzyme purified from 'litsusu' tree (Wrightiana calysina) as a proteoIytic enzyme. Milchwissenschaft 39, 156-158

Prins J (1988) La aplicación de enzimas en la industria de lácteos y derivados. Ind Lacteas Esp 110, 49-60

Rasteiro J (1905) Fabrico e comércio do queijo em Portugal. Congresso de Leitaria, Olivinicultura e Indústria do Azeite, vol I. Real Associação Central de Agricultura Portuguesa

Sponcet M, Sifflet P, Michallet A (1985) Avances en la utilizacion de coagulantes en la industria láctea. Ind Lacteas Esp 85, 90-104

Tsouli J (1974) Étude comparée de l'activité enzymatique de 3 variétés d'artichauts du genre Cynara cardunculus $L$. sur la coagulation du lait. Lait 44, 415421

Vasconcelos MMP (1991) Estudo do Queijo de Azeitão. Melhoramento da tecnologia tradicional e sua influência nas características do queijo. Dissertação apresentada ao INIA para prestação de provas de acesso à categoria de Inv Auxiliar NTLD, ENTPA, INIA, Lisboa

Vasconcelos MMP, Martins APL, Carreira DFC (1989) Contribuição para o estudo do queijo de Azeitão. Tecnol Agrár 2 ( $n^{\circ}$ esp Outubro), 9-15

Vieira De SÁ F (1974) Cuajos vegetales. Rev Esp Leche 92, 107-109

Vieira De SÁ F, Barbosa M (1972) Cheese-making with a vegetable rennet from cardo (Cynara carduncuIus). J Dairy Res 39, 335-343 